\title{
Somatomedin- $\mathrm{C}$ and zinc status in rats as affected by $\mathrm{Zn}$, protein and food intake
}

\author{
BY ZAFRALLAH T. COSSACK* \\ The Veterans Administration Medical Center, Medical Research (151), Allen Park, \\ Michigan 48101, USA
}

(Received 28 June 1985 - Accepted 20 January 1986)

\begin{abstract}
1. The objective of the present experiment was to study the level of plasma somatomedin-C (SM-C) and the status of zinc in rats as affected by three levels of $\mathrm{Zn}$ given in combinations with two levels of protein.

2. Six groups of rats were fed, for $21 \mathrm{~d}$, on six different diets based on combinations of two levels of dietary protein (low protein, $75 \mathrm{~g} / \mathrm{kg}$; high protein, $200 \mathrm{~g} / \mathrm{kg}$ ) and three levels of zinc (low $\mathrm{Zn}, 0.9 \mu \mathrm{g} / \mathrm{kg}$; moderate $\mathrm{Zn}$, $55 \mu \mathrm{g} / \mathrm{kg}$; high $\mathrm{Zn}, 110 \mu \mathrm{g} / \mathrm{kg}$ ). All groups were pair-fed with the group receiving the low- $\mathrm{Zn}$-low-protein diet. An additional group of six rats served as an ad lib.-fed control group and was fed on a diet that contained $55 \mu \mathrm{g}$ $\mathrm{Zn} / \mathrm{kg}$ and $200 \mathrm{~g}$ protein $/ \mathrm{kg}$ ad lib.

3. Body-weight gain and food intake were recorded daily. Rats were killed at the end of the experimental period (21 d). $\mathrm{Zn}$ was assayed in plasma, tibia and liver by atomic absorption technique. Plasma SM-C was assayed by radioimmunoassay.

4. In rats given the low- $\mathrm{Zn}$-low-protein diet, the level of plasma SM-C increased in response to the increase in the amount of $\mathrm{Zn}$ or $\mathrm{Zn}$ and protein in the diet. However, no change was observed when the level of protein alone was increased.

5. Among all groups tested, ad lib.-fed rats showed the highest level of plasma SM-C. Thus it may be concluded that a balanced diet combined with adequate food intake is necessary to maintain an optimal level of plasma SM-C.
\end{abstract}

Somatomedins are peptides of low molecular weight which are regulated by growth hormone (GH; Salmon \& Daughaday, 1957), nutrition (Phillips \& Young, 1976a; Phillips \& Orawski, 1977; Phillips et al. 1978; Cossack, 1984) and insulin (Phillips \& Orawski, 1977). It has been documented that GH produces growth indirectly through generation of a serum factor(s), somatomedin (SM), which acts directly to produce cartilage proliferation and linear skeletal growth (Daughaday et al. 1972). However, low levels of SM with associated growth failure, despite elevation of $\mathrm{GH}$, were noted in Laron-type dwarfism (Laron et al. 1966) and in protein-energy malnutrition (Tanner et al. 1966; Hintz et al. 1978). On the other hand, a normal level of SM associated with a low level of GH was observed in children who were hyperphagic and hyperinsulinaemic after hypothalamic surgery (Costin et al. 1976).

The recent establishment of a method(s) for measuring the activity of SM (Van den Brande \& Du Caju, 1974; Furlanetto et al. 1977) has prompted further investigation of the roles of many factors in growth. However, studies on the effect of some nutrients on the activity of SM in man and experimental animals have not been conclusive. An inverse relation between dietary fat and plasma SM was observed in rats (Reeves et al. 1979). Moreover, the level of SM increased with increasing levels of protein and no change was observed in the levels of GH (Reeves et al. 1979; Prewitt et al. 1982). Most recently, we reported a significant decrease in the level of somatomedin-C (SM-C) in zinc-deficient rats when they were compared with pair-fed, continuously-pair-fed and ad lib.-fed rats (Cossack, 1984). In the same study, we observed that plasma SM-C correlated with $\mathrm{Zn}$ concentration in the tibia $(r 0.79, P<0.005)$ and with body-weight gain $(r 0.96, P<0.001)$. We concluded that growth retardation associated with $\mathrm{Zn}$ deficiency could be related to the adverse effect of $\mathrm{Zn}$ deficiency on the generation of SM-C, and $\mathrm{Zn}$ supplementation reverses this effect.

* Present address: Institute of Physiology, Odense University, Campusvej 55, Odense M, Dk-5230, Denmark. 
Table 1. Composition of experimental diets* $(\mathrm{g} / \mathrm{kg}$ diet $)$

\begin{tabular}{|c|c|c|c|c|c|c|}
\hline \multirow[b]{2}{*}{ Ingredient } & \multicolumn{6}{|c|}{ Diet } \\
\hline & LZLP & MZLP & HZLP & LZHP & MZHP & HZHP \\
\hline Egg-white solids, spray-dried & $93 \cdot 750$ & $93 \cdot 750$ & $93 \cdot 750$ & $225 \cdot 000$ & $225 \cdot 000$ & $225 \cdot 000$ \\
\hline Glucose monohydrate (dextrose) & $756 \cdot 246$ & 756.095 & $756 \cdot 246$ & $624-996$ & $624 \cdot 996$ & $624 \cdot 694$ \\
\hline Cellulose powder & $30 \cdot 000$ & $30 \cdot 000$ & 30.000 & $30 \cdot 000$ & $30 \cdot 000$ & $30 \cdot 000$ \\
\hline Oil, maize & $100 \cdot 000$ & $100 \cdot 000$ & $100 \cdot 000$ & $100 \cdot 000$ & $100 \cdot 000$ & 100.000 \\
\hline Mineral mixture & $10 \cdot 000$ & $10 \cdot 000$ & $10 \cdot 000$ & $10 \cdot 000$ & $10 \cdot 000$ & $10 \cdot 000$ \\
\hline Vitamin mixture $\ddagger$ & $10 \cdot 000$ & $10 \cdot 000$ & $10 \cdot 000$ & $10 \cdot 000$ & $10 \cdot 000$ & $10 \cdot 000$ \\
\hline Biotin & 0.004 & 0.004 & 0.004 & 0.004 & 0.004 & 0.004 \\
\hline $\mathrm{ZnSO}_{4} \cdot 7 \mathrm{H}_{2} \mathrm{O}$ & 0.000 & $0 \cdot 151$ & $0 \cdot 302$ & 0.000 & 0.151 & 0.302 \\
\hline
\end{tabular}

* L, low; M, moderate; $\mathrm{H}$, high; $\mathbf{P}$, protein; $\mathrm{Z}$, zinc.

$\uparrow$ Supplied (g/kg diet): calcium phosphate, dibasic $19 \cdot 767$, potassium chloride $2 \cdot 2882$, sodium chloride $0 \cdot 7781$, magnesium sulphate $2 \cdot 4752, \mathrm{MnSO}_{4} \cdot \mathrm{H}_{2} \mathrm{O} 0 \cdot 1662, \mathrm{FeSO}_{4} \cdot 7 \mathrm{H}_{2} \mathrm{O} 0 \cdot 20$, potassium iodate $0 \cdot 0004$, cupric sulphate 0.0151 .

$\ddagger$ Teklad test diets; Teklad, Madison, Wisconsin, supplied (g/ $\mathrm{kg}$ diet): maize starch $4 \cdot 66$, choline dihydrogen citrate 3.496, ascorbic acid $(97.5 \%) 1 \cdot 1016, \alpha$-tocopherol $(500 \mu \mathrm{g} / \mathrm{g}) 0 \cdot 242, p$-aminobenzoic acid $0 \cdot 11$, inositol $0 \cdot 11$ and $(\mathrm{mg} / \mathrm{g}$ diet) : biotin 0.441 , cyanocobalamin $(1 \mathrm{~g} / 1$ mannitol) $29 \cdot 74$, calcium pantothenate 66.08 , pteroylmonoglutamic acid 1.982 , menadione $49 \cdot 56$, nicotinic acid $99 \cdot 12$, pyridoxine hydrochloride 22.03 , riboflavin 22.03 , thiamin hydrochloride 22.03 , retinoic acid $(500 \mu \mathrm{g} / \mathrm{g}) 39 \cdot 65$, ergocalciferol $(500 \mu \mathrm{g} / \mathrm{g}) 4.405$.

The increased growth rate in the world population may severely limit the supply of protein. Malnourished populations have often been supplemented with grain sources of protein. It has been shown that poor-quality sources of protein should be given at relatively high levels (compared with high-quality sources) to promote optimal growth (Cossack \& Weber, 1983). Moreover, the addition of $\mathrm{Zn}$ has been shown to improve the biological value of poor-quality sources of protein (Boloorforooshan \& Markakis, 1977). Thus, the objective of the present study was to investigate the changes in growth rate, plasma SM-C and $\mathrm{Zn}$ status in rats given two levels of dietary protein in combinations with three levels of $\mathrm{Zn}$.

\section{MATERIALS AND METHODS}

Thirty-six white, male, growing rats (35-d-old) of the Holtzman strain (Holtzman Co., Madison, Wisconsin) were given six test diets (Table 1) based on combinations (Table 2) of two levels of protein (low protein (LP), $75 \mathrm{~g} / \mathrm{kg}$; high protein (HP), $200 \mathrm{~g} / \mathrm{kg}$ ), and three levels of $\mathrm{Zn}$ (low $\mathrm{Zn}(\mathrm{LZ}$ ), $0.9 \mu \mathrm{g} / \mathrm{kg}$; medium $\mathrm{Zn}(\mathrm{MZ}$ ), $55 \mu \mathrm{g} / \mathrm{kg}$; high $\mathrm{Zn}(\mathrm{HZ}$ ), $110 \mu \mathrm{g} / \mathrm{kg}$ ). The basal diet contained $0.9 \mu \mathrm{g} \mathrm{Zn} / \mathrm{kg}$ by analysis. The animals were housed in individual stainless-steel wire-bottom cages under $12 \mathrm{~h}$ light-12 h dark periods in a room at a controlled temperature $\left(22^{\circ}\right)$. Initial body-weights of the rats ranged from 95 to $100 \mathrm{~g}$. The rats were given a standard diet (rat chow, Purina Co., St Louis, MO) for $4 \mathrm{~d}$ after which they were randomly allocated to the six experimental diets. The amount of diet given to rats in each group matched the intake of their counterparts of the group given the LZLP diet. An additional group of six rats served as an ad lib.-fed control group and was given the MZHP diet ad lib. The rats were given free access to distilled-deionized water throughout the experimental period ( $21 \mathrm{~d}$ ). Rats were mildly anaesthetized with diethyl ether and blood drawn by heart puncture after which they were killed by decapitation. The blood was collected (using EDTA as anticoagulant) in plastic tubes free of $\mathrm{Zn}$, immediately centrifuged $(2000 \mathrm{~g})$ for $10 \mathrm{~min}$ and plasma was separated and kept at $-60^{\circ}$ for $\mathrm{SM}-\mathrm{C}$ 
Table 2. Food intake, body-weight gain, concentration of zinc in tissues and levels of plasma somatomedin-C

(Mean values and standard deviations)

\begin{tabular}{|c|c|c|c|c|c|c|c|c|c|}
\hline & \multirow{3}{*}{$\begin{array}{c}\text { Dietary } \\
\text { protein } \\
(\mathrm{g} / \mathrm{kg}) \\
75 \ldots \\
200 \ldots\end{array}$} & \multicolumn{6}{|c|}{$\mathrm{Zn}$ content $(\mu \mathrm{g} / \mathrm{kg})$} & & \\
\hline & & \multicolumn{2}{|c|}{$\begin{array}{l}0.9 \\
\text { LZLP } \\
\text { LZHP }\end{array}$} & \multicolumn{2}{|c|}{$\begin{array}{c}55 \\
\text { MZLP } \\
\text { MZHP }\end{array}$} & \multicolumn{2}{|c|}{$\begin{array}{c}110 \\
\text { HZLP } \\
\text { HZHP }\end{array}$} & \multicolumn{2}{|c|}{$\begin{array}{l}\text { Ad lib.-fed } \\
\text { controls }\end{array}$} \\
\hline & & Mean & $\mathrm{SD}$ & Mean & SD & Mean & $\mathrm{SD}$ & Mean & SD \\
\hline $\begin{array}{l}\text { Food intake ( } \mathrm{g} / \text { rat } \\
\text { per d) }\end{array}$ & $\begin{array}{r}75 \\
200\end{array}$ & $\begin{array}{l}8 \cdot 36^{\mathrm{a}} \\
8 \cdot 36\end{array}$ & $\underline{0.8}$ & $\begin{array}{l}8 \cdot 36 \\
8 \cdot 36\end{array}$ & - & $\begin{array}{l}8 \cdot 36 \\
8 \cdot 36\end{array}$ & $-\}$ & $15 \cdot 0^{\mathrm{b}}$ & $2 \cdot 6$ \\
\hline $\begin{array}{l}\text { Body-wt gain (g/rat } \\
\text { per d) }\end{array}$ & $\begin{array}{r}75 \\
200\end{array}$ & $\begin{array}{l}0 \cdot 9^{\mathrm{a}} \\
1 \cdot 1^{\mathrm{a}}\end{array}$ & $\begin{array}{l}0 \cdot 1 \\
0 \cdot 1\end{array}$ & $\begin{array}{l}1 \cdot 7^{\mathrm{b}} \\
2 \cdot 2^{\mathrm{c}}\end{array}$ & $\begin{array}{l}0 \cdot 1 \\
0 \cdot 3\end{array}$ & $\begin{array}{l}1 \cdot 6^{\mathrm{b}} \\
2 \cdot 3^{\mathrm{c}}\end{array}$ & $\left.\begin{array}{l}0 \cdot 3 \\
0.2\end{array}\right\}$ & $5 \cdot 3^{d}$ & $1 \cdot 1$ \\
\hline Plasma Zn $(\mu \mathrm{g} / 1)$ & $\begin{array}{r}75 \\
200\end{array}$ & $\begin{array}{l}540^{\mathrm{a}} \\
540^{\mathrm{a}}\end{array}$ & $\begin{array}{r}6.0 \\
10.0\end{array}$ & $\begin{array}{l}1410^{\mathrm{v}} \\
1810^{\mathrm{c}}\end{array}$ & $\begin{array}{l}20 \cdot 0 \\
25 \cdot 0\end{array}$ & $\begin{array}{l}1470^{\mathrm{b}} \\
1790^{\mathrm{c}}\end{array}$ & $\left.\begin{array}{l}12 \cdot 0 \\
26 \cdot 0\end{array}\right\}$ & $1720^{\mathrm{e}}$ & $10 \cdot 0$ \\
\hline Tibia $\operatorname{Zn}(\mu \mathrm{g} / \mathrm{g}$ dry wt $)$ & $\begin{array}{r}75 \\
200\end{array}$ & $\begin{array}{l}116^{a} \\
120^{a}\end{array}$ & $\begin{array}{r}8 \cdot 0 \\
15 \cdot 0\end{array}$ & $\begin{array}{l}213^{\mathrm{b}} \\
236^{\mathrm{c}}\end{array}$ & $\begin{array}{r}9.0 \\
15 \cdot 0\end{array}$ & $\begin{array}{l}217^{\mathrm{b}} \\
250^{\mathrm{c}}\end{array}$ & $\left.\begin{array}{l}11 \cdot 0 \\
19 \cdot 0\end{array}\right\}$ & $273^{d}$ & $12 \cdot 0$ \\
\hline Liver $\operatorname{Zn}(\mu \mathrm{g} / \mathrm{g}$ dry wt) & $\begin{array}{r}75 \\
200\end{array}$ & $\begin{array}{c}92^{\mathrm{a}} \\
112^{\mathrm{c}}\end{array}$ & $\begin{array}{l}19 \cdot 0 \\
10.0\end{array}$ & $\begin{array}{l}136^{\mathrm{b}} \\
150^{\mathrm{d}}\end{array}$ & $\begin{array}{l}14.0 \\
15.0\end{array}$ & $\begin{array}{l}136^{b} \\
140^{b d}\end{array}$ & $\left.\begin{array}{l}16.0 \\
11.0\end{array}\right\}$ & $138^{\text {hd }}$ & $9 \cdot 0$ \\
\hline $\begin{array}{l}\text { Somatomedin-C: } \\
\text { units/ml plasma } \\
\% \text { of ad-lib. } \\
\text { control } \\
\% \text { of pair-fed } \\
\text { control }\end{array}$ & $\begin{array}{r}75 \\
200 \\
75 \\
200 \\
75 \\
200\end{array}$ & $\begin{array}{l}0 \cdot 90^{\mathrm{a}} \\
0 \cdot 89^{\mathrm{a}} \\
39 \cdot 0 \\
38 \cdot 7 \\
65 \cdot 7 \\
65 \cdot 0\end{array}$ & $\begin{array}{l}0 \cdot 1 \\
0 \cdot 1 \\
- \\
- \\
-\end{array}$ & $\begin{array}{l}1 \cdot 24^{\mathrm{b}} \\
1 \cdot 37^{\mathrm{b}} \\
53 \cdot 9 \\
59 \cdot 6 \\
91 \cdot 0 \\
100\end{array}$ & $\begin{array}{l}0 \cdot 3 \\
0 \cdot 1 \\
- \\
- \\
- \\
-\end{array}$ & $\begin{array}{l}1 \cdot 22^{\mathrm{b}} \\
1 \cdot 20^{\mathrm{b}} \\
53 \cdot 0 \\
52 \cdot 2 \\
89 \cdot 0 \\
88 \cdot 0\end{array}$ & $\left.\begin{array}{l}0.1 \\
0.1\end{array}\right\}$ & $167 \cdot 9$ & $0 \cdot 3$ \\
\hline
\end{tabular}

a d Mean values with unlike superscript letters were significantly different; minimum level of significance; $P<0.05$

$\uparrow$ LZLP group was fed ad lib. The intake of the other groups, except the ad lib.-fed group, matched the intake of their counterparts of the LZLP group. For details, see p. 164.

determination using a radioimmunoassay method (reagents including SM-C standards and controls were contributed by Nichols Institute, CA, USA, and the basic method is described by Furlanetto et al. 1977). A portion of the blood was drawn using $\mathrm{Zn}$-free heparin as recommended for the determination of plasma $\mathrm{Zn}$ (Whitehouse et al. 1982). Tibia and liver were isolated, cleaned from debris with distilled-deionized water, lyophilized, weighed and digested with nitric acid for the determination of $\mathrm{Zn}$ using a flame atomic absorption spectrophotometer (Model 406; Perkin Elmer, Norwalk, Conn.).

Duncan's multiple-range test was employed for statistical analysis (Snedecor \& Cochran, 1968).

\section{RESULTS}

Table 2 shows body-weight gain, concentrations of $\mathrm{Zn}$ in tibia, plasma and liver and the levels of plasma SM-C in rats. Body-weight gains in the groups of rats given $\mathrm{Zn}$-deficient diets (LZLP and LZHP) were significantly $(P<0.001)$ lower when compared with those given high-Zn diets (HZLP and HZHP) regardless of the level of protein in the diet. Increasing the level of protein in the LZLP diet did not result in a significant increase in body-weight (LZLP v. LZHP). However, body-weight gain increased significantly $(P<0.005)$ when the level of protein was increased from 75 to $200 \mathrm{~g} / \mathrm{kg}$ in combination with MZ or HZ (MZLP $v$. MZHP and HZLP $v$. HZHP).

An increase in plasma $\mathrm{Zn}(P<0.005)$ concentration was observed in response to the high 


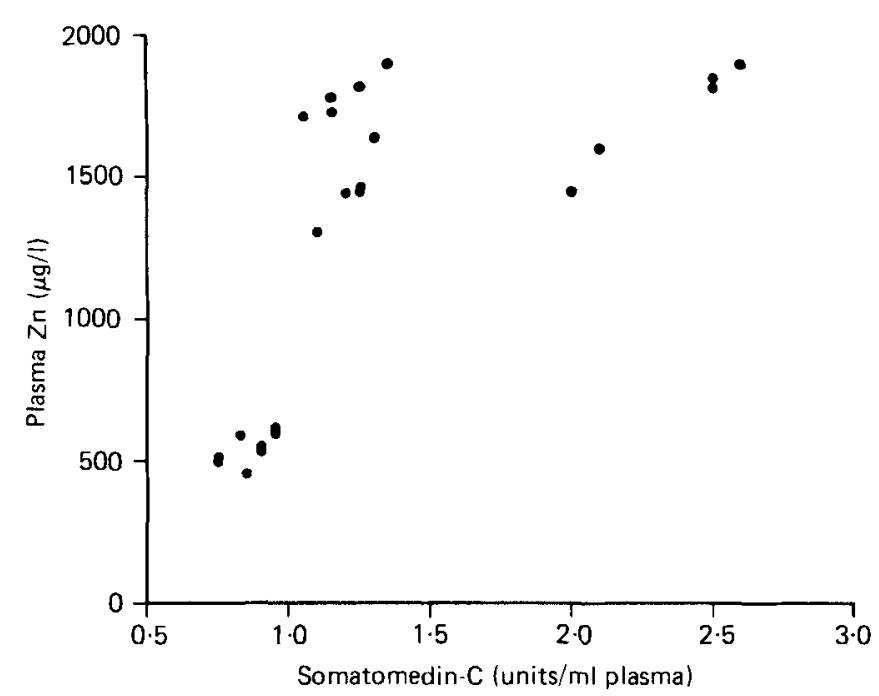

Fig. 1. Relation between the level of plasma somatomedin-C (SM-C) and the concentration of plasma $\mathrm{Zn}$ in rats.

level of protein in combination with $\mathrm{MZ}$ or $\mathrm{HZ}$. Rats given the $\mathrm{MZ}$ diet showed a significant increase $(P<0.0001)$ in the concentration of $\mathrm{Zn}$ in plasma regardless of the level of protein. No additional effect was observed when rats were given the $\mathrm{HZ}$ diet.

The concentration of $\mathrm{Zn}$ in the tibia increased significantly $(P<0 \cdot 005)$ in response to an increased level of dietary protein in rats given MZLP or HZLP diets (Table 2). The concentration of $\mathrm{Zn}$ in the liver increased significantly in response to $\mathrm{Zn}$ (LZLP $v$. MZLP, $P<0.001$ ) and also in response to increased level of dietary protein (LZLP $v$. LZHP, $P<0.002$ ). Maximum concentration of liver $\mathrm{Zn}$ occurred when both protein and $\mathrm{Zn}$ were increased in the diet (MZHP).

Regardless of the level of protein intake, rats given the $\mathrm{MZ}$ or $\mathrm{HZ}$ diet exhibited significantly higher levels of plasma SM-C $(P<0.005)$ compared with $\mathrm{Zn}$-deficient rats (Table 2). Among pair-fed groups, maximum level of SM-C was observed in the group of rats given $200 \mathrm{~g}$ protein $/ \mathrm{kg}$ diet containing $55 \mu \mathrm{g} \mathrm{Zn} / \mathrm{kg}$ (MZHP). In addition, further increase in $\mathrm{Zn}$ content to $100 \mu \mathrm{g} / \mathrm{kg}$ (as in HZHP and HZLP groups) did not result in a linear increase in the level of SM-C. Among all groups tested, the ad lib.-fed group showed the highest level of SM-C. The relations between the level of plasma SM-C and the concentration of $\mathrm{Zn}$ in plasma or tibia are shown in Figs 1 and 2 respectively.

\section{DISCUSSION}

The six different diets used in the present study were designed so that the effect of $\mathrm{Zn}$ or protein restriction, or both, on the level of plasma SM-C could be tested. This was achieved by comparing plasma SM-C levels in the different experimental groups with those of the pair-fed control (MZHP) and ad lib.-fed control groups (Table 2). The difference in the level of SM-C between the ad lib.-fed and pair-fed control groups reflected the effect of anorexia, since both groups were given the same diet except that the pair-fed control rats were given a restricted amount of food which matched the intake of their counterparts of the LZLP group. All experimental diets used in the present study were based on the same ingredients, and covered the nutrient requirements of the growing rat (except where $\mathrm{Zn}$ deficiency or 


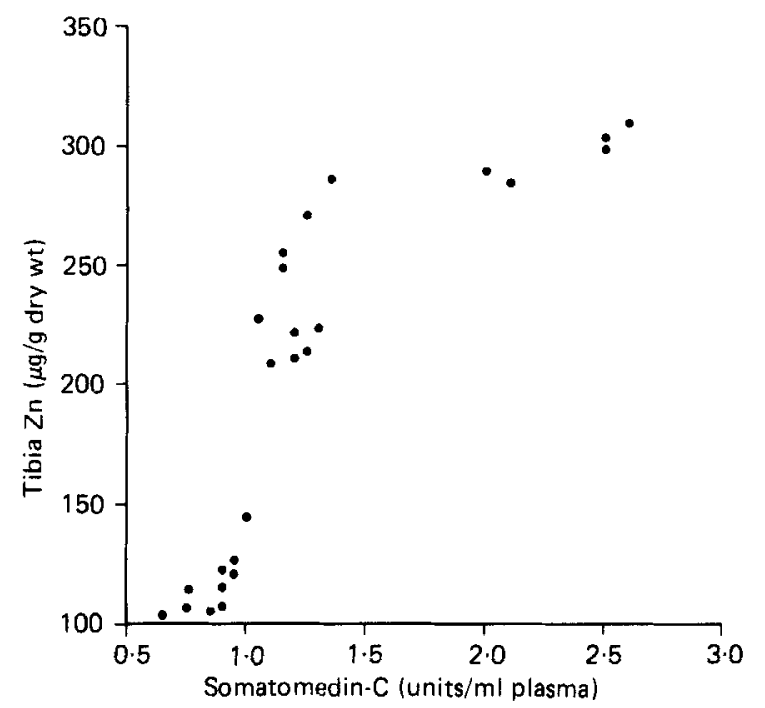

Fig. 2. Relation between the level of plasma somatomedin-C (SM-C) and the concentration of tibia $\mathrm{Zn}$ in rats.

protein restriction, or both, were indicated), and have been extensively used in studies involving $\mathrm{Zn}$ nutrition and metabolism in rats.

The utilization of $\mathrm{Zn}$ and protein are interdependent in animals (Hsue \& Anthony, 1975; Magee \& Grainger, 1979; Wallwork et al. 1983) and man (Sandström \& Cederblad, 1980; Cossack \& Prasad, 1983). Protein utilization is impaired in $\mathrm{Zn}$-deficient states (Sandstead, 1973; Hsue \& Anthony, 1975). On the other hand, the biological availability of $\mathrm{Zn}$ is dependent on the source and level of dietary protein (Cossack \& Prasad, 1983; Wallwork et al. 1983). In the present investigation, body-weight values (Table 2) suggested that in rats given the LZ diet, growth was improved by the addition of $\mathrm{Zn}$ regardless of the level of protein in the diet (LZLP $v$. MZLP or HZLP, and LZHP v. MZHP or HZHP). Moreover, in rats given the LP diet and adequate $\mathrm{Zn}$ (MZLP or HZLP), growth was improved by increasing the level of dietary protein (MZLP $v$. HZHP or HZLP $v$. HZHP). However, increasing the level of protein in the diet did not result in an improvement in the growth of rats given the LZLP diet (LZLP $v$. LZHP). These findings are consistent with the results of Pedersen \& Eggum (1983) who gave rats 80, 160 and $240 \mathrm{~g}$ casein $/ \mathrm{kg}$-based diets with $3,6,9$ or $50 \mu \mathrm{g} \mathrm{Zn} / \mathrm{kg}$ diet.

When rats were given 55 or $110 \mu \mathrm{g} \mathrm{Zn} / \mathrm{kg}$, plasma $\mathrm{Zn}$ concentration increased significantly in response to the higher level of protein in the diet. This finding is in contrast to the report of Wallwork et al. (1983) who gave rats 60,110 and $150 \mathrm{~g}$ egg-white protein $/ \mathrm{kg}$ with 6 , 12 or $18 \mu \mathrm{g} \mathrm{Zn} / \mathrm{kg}$. This discrepancy may be due to the differences in the levels of $\mathrm{Zn}$ and protein being given. Van Campen \& House (1974) reported an increased concentration of plasma $\mathrm{Zn}$ in rats given $150 \mathrm{~g}$ casein $/ \mathrm{kg}$ in the diet compared with those given $50 \mathrm{~g}$ casein $/ \mathrm{kg}$; thus, their results are in support of our findings. Concentrations of $\mathrm{Zn}$ in the tibia and liver followed a similar trend with regard to the effect of dietary protein or $\mathrm{Zn}$ content or both. This effect was more pronounced in the tibia. Increasing the level of $\mathrm{Zn}$ or protein, or both, resulted in an increase in the concentration of $\mathrm{Zn}$ in the tibia and liver of rats. These findings are in accordance with previous reports (Magee \& Grainger, 1979; Pedersen \& Eggum, 1983; Wallwork et al. 1983). 
Dietary composition is one of the most important factors affecting the synthesis of SM in man and experimental animals (Phillips \& Young, 1976a; Phillips \& Orawski, 1977; Prewitt et al. 1982; Cossack, 1984) and, thus, influences growth and development. Improvement in growth in response to $\mathrm{Zn}$ supplementation has been reported in man (Collip et al. 1982; Walraven \& Hambidge, 1983; Prasad \& Cossack, 1984) and experimental animals (Magee \& Grainger, 1979; Wallwork et al. 1983). Recently, Cossack (1984) reported that plasma SM-C concentration is dependent on, in addition to other factors, the level of $\mathrm{Zn}$ in the diet. Furthermore, plasma SM-C correlated significantly with the $\mathrm{Zn}$ status of the rat. In the present study plasma SM-C concentration increased significantly when the $\mathrm{Zn}$-deficient rats were given 55 or $110 \mu \mathrm{g} \mathrm{Zn} / \mathrm{kg}$ regardless of the level of dietary protein (Table 2). Increasing the level of dietary protein from 75 to $200 \mathrm{~g} / \mathrm{kg}$, in rats given $\mathrm{LZ}$ diets, did not result in an increase in the concentration of SM-C in plasma. This finding conflicts with the results of Prewitt et al. (1982) who reported a linear increase in plasma SM-C concentration as protein intake increased from 50 to $150 \mathrm{~g} / \mathrm{kg}$, and declined when protein increased to 250 and $500 \mathrm{~g} / \mathrm{kg}$. This discrepancy may be the result of the difference in the feeding regimen: rats in the present study were pair-fed, while in the experiment of Prewitt et al. (1982) rats were fed ad lib. Restriction of food intake resulted in a $40 \%$ decrease in plasma SM-C concentration in the pair-fed control group (MZHP) as compared with the ad lib.-fed control group (Table 2). In this connection, Takano et al. (1978) reported a 74\% decrease in SM concentration in rats fasted for $24 \mathrm{~h}$ compared with controls. Moreover, Phillips \& Young (1976b), Takano et al. (1978), and Yeh \& Aloia (1978) postulated that adequate food intake is required for the maintenance of normal levels of SM, and the generation of SM may be modulated by the processing of nutrients, thus providing support for our findings.

The concentration of $\mathrm{Zn}$ in the tibia or plasma has been used as an indicator of $\mathrm{Zn}$ status in the rat. The present study shows that the level of plasma SM-C was increased in response to the increase in the concentration of $\mathrm{Zn}$ in the plasma (Fig. 1) or in the tibia (Fig. 2). However, the relations between the level of plasma SM-C and plasma $\mathrm{Zn}$ concentration, and plasma SM-C and the concentration of $\mathrm{Zn}$ in the tibia, were not linear.

It may be concluded from the results of the present study that: (1) the level of plasma SM-C was adversely affected due to the restriction of food intake in the rat; (2) increasing the level of protein in the $\mathrm{Zn}$-deficient diet given to growing rats did not result in an increase in the level of SM-C, however, increasing the level of $\mathrm{Zn}$ in the low-protein diet resulted in a significant increase in the level of SM-C; (3) a balanced diet combined with adequate food intake is necessary to maintain normal levels of plasma SM-C.

\section{REFERENCES}

Boloorforooshan, M. \& Markakis, P. (1977). Journal of Food Science 42, 1671-1672.

Collip, P. J., Castro-Managa, M. C., Petrovic, M., Thomas, J., Cheruvansky, T., Yao Chen, S. \& Sassman, H. (1982). Annals of Nutrition and Metabolism 26, 287-290.

Cossack, Z. T. (1984). Experientia 40, 498-500.

Cossack, Z. T. \& Prasad, A. S. (1983). Nutrition Research 3, 23-31.

Cossack, Z. T. \& Weber, C. W. (1983). Nutrition Reports International 28, 203-217.

Costin, G., Kogut, M. D., Phillips, L. S. \& Daughaday, W. H. (1976). Journal of Clinical Endocrinology and Metabolism 42, 370-375.

Daughaday, W. H., Hall, K., Raben, M. S., Salmon, W. D., van den Brande, J. L. \& van Wyke, J. J. (1972). Nature 235, $107-108$

Furlanetto, R. W., Underwood, L. E., van Wyke, J. J. \& D'Ercole, A. J. (1977). Journal of Clinical Investigation 60, 648-657.

Hintz, R. L., Suskind, R., Amatayakul, K., Thanagkul, O. \& Olson, R. (1978). Journal of Pediatrics 29, $153-156$. Hsue, J. M. \& Anthony, W. L. (1975). Journal of Nutrition 105, 26-30.

Laron, Z., Pertzelan, A. \& Mannheimer, S. (1966). Israel Journal of Medicine 2, 152-155. 
Magee, A. C. \& Grainger, F. P. (1979). Nutrition Reports International 20, 771-776.

Pedersen, B. \& Eggum, B. O. (1983). Nutrition Reports International 27, 441-453.

Phillips, L. S. \& Orawski, A. T. (1977). Diabetes 26, 864-869.

Phillips, L. S., Orawski, A. T. \& Belosky, D. C. (1978). Endocrinology 103, 121-127.

Phillips, L. S. \& Young, H. S. (1976a). Diabetes 25, 516-526.

Phillips, L. S. \& Young, H. S. (1976b). Endocrinology 99, 304-314.

Prasad, A. S. \& Cossack, Z. T. (1984). Annals of Internal Medicine 100, 367-371.

Prewitt, T. E., D’Ercole, A. T., Switzer, B. R. \& van Wyke, J. J. (1982). Journal of Nutrition 112, $144-150$.

Reeves, R. D., Dickinson, L., Lee, J., Kilgore, B., Branham, B. \& Elders, M. J. (1979). Journal of Nutrition 109, 603-620.

Salmon, W. D. Jr \& Daughaday, W. H. (1957). Journal of Laboratory and Clinical Medicine 49, 825-836.

Sandstead, H. H. (1973). American Journal of Clinical Nutrition 26, 790-793.

Sandström, B. \& Cederblad, A. (1980). American Journal of Clinical Nutrition 33, 1778-1783.

Snedecor, G. W. \& Cochran, W. G. (1968). Statistical Methods, pp. 150-162. Ames, Iowa: Iowa State University Press.

Takano, K., Hizuka, N., Kawai, K. \& Shizume, K. (1978). Acta Endocrinologica 87, 485-494.

Tanner, J. M., Whitehouse, R. H. \& Takaishi, M. (1966). Archives of Diseases of Children 41, 545-551.

Van Campen, D. \& House, W. A. (1974). Journal of Nutrition 104, 8491.

Van den Brande, J. L. \& Du Caju, M. V. L. (1974). Acta Endocrinologica 75, 233-242.

Wallwork, J. C., Johnson, L. K., Milne, D. B. \& Sandstead, H. H. (1983). Journal of Nutrition 113, 1307-1320.

Walraven, P. A. \& Hambidge, K. M. (1983). American Journal of Clinical Nutrition 29, 1114-1121.

Whitehouse, R. C., Prasad, A. S., Rabbani, P. I. \& Cossack, Z. T. (1982). Clinical Chemistry 28, 475-480.

Yeh, J. \& Aloia, J. F. (1978). Metabolism 27, 507-509. 